\title{
Kualitas Dan Ketahanan Hidup Perempuan Lansia
}

\author{
Quality And Survival Elderly Woman
}

\section{Musrayani Usman', Hasbi ${ }^{2}$, Sakaria $^{3}$, Hariashari Rahim ${ }^{4}$, Atma Ras ${ }^{5}$}

\footnotetext{
${ }^{l}$ Dosen Departemen Sosiologi, Fakultas Ilmu Sosial dan Ilmu Politik Universitas Hasanuddin, Makassar, Indonesia, Email: yaniunhas2@gmail.com

${ }^{2}$ Dosen Departemen Sosiologi, Fakultas Ilmu Sosial dan Ilmu Politik Universitas Hasanuddin, Makassar, Indonesia, Email: hasbimarissangan@gmail.com

${ }^{3}$ Dosen Departemen Sosiologi, Fakultas Ilmu Sosial dan Ilmu Politik Universitas Hasanuddin, Makassar, Indonesia, Email: sakaria_anwar_ipb@yahoo.com

${ }^{4}$ Dosen Departemen Sosiologi, Fakultas Ilmu Sosial dan Ilmu Politik Universitas Hasanuddin, Makassar, Indonesia, Email: ashari.arrahim@unhas.ac.id

${ }^{5}$ Dosen Departemen Sosiologi, Fakultas Ilmu Sosial dan Ilmu Politik Universitas Hasanuddin, Makassar, Indonesia, Email: atmakucing@gmail.com
}

\section{A R T I CL E I N F O}

\section{How to Cite: \\ Usman, M., Hasbi, Sakaria, Rahim, H, \& Ras, A. (2021). Kualitas dan Ketahanan Hidup Perempuan Lansia. Hasanuddin Journal of Sociology (HJS), 3(1), 76-82.}

Keywords: Quality, Survival, Elderly Woman

Kata Kunci: Kualitas, Ketahanan Hidup, Pengaruh Hidup, Perempuan Lansia

\begin{abstract}
A B S T R A C T
Common problems faced by elderly women are the greater the number of elderly women below the poverty line, the weakening of kinship in the family, sometimes they get less attention, respect and respect, lack of elderly services from professional staff, and have not institutionalized and cultivated the development of the welfare of the elderly, especially elderly women. . then the formulation of the problem of this study is to identify the dominant factors that affect the quality of life of elderly women and how the resilience of elderly women.

This study applies a qualitative descriptive method with a phenomenological research approach that seeks to understand the meaning of events and their relation to people in certain situations. Based on the results of the study, changes that occur in elderly women include physical changes, psychosocial changes and environmental changes.

From the results of the study, most of the respondents had a moderate quality of life. From the problems faced by elderly women, among others, due to physical influences, psychosocial influences and the environment, the most dominating for elderly women was economic problems in the family which required them to participate in fulfilling family needs.
\end{abstract}

\section{ABSTRAK}

Permasalahan umum yang dihadapi perempuan lansia adalah makin besar

* Corresponding author. Telp.: -

E-mail address: rizkysintiahputri@gmail.com 
jumlah perempuan lansia di bawah garis kemiskinan, makin melemahnya kekerabatan dalam keluarga terkadang mereka kurang mendapatkan perhatian, dihargai dan dihormati, kurangnya pelayanan lansia dari tenaga professional, dan belum melembaga dan membudaya pembinaan kesejahteraan lansia khususnya perempuan lansia. maka rumusan masalah dari penelitian ini adalah mengidentifikasi faktor dominan yang mempengaruhi kualitas hidup perempuan lansia dan bagaimana ketahanan perempuan lansia.

Penelitian ini menerapkan metode deskriptif kualitatif dengan pendekatan penelitian dalam pandangan fenomelogis yang berusaha memahami arti dari peristiwa dan kaitannya terhadap orang dalam situasi tertentu. Berdasarkan hasil penelitian, perubahan yang terjadi pada perempuan lansia meliputi perubahan fisik, perubahan psikososial dan perubahan lingkungan.

Dari hasil penelitian sebagian besar responden memiliki kualitas hidup yang sedang, Dari permasalahan yang dihadapi perempuan lansia antara lain karena pengaruh fisik, pengaruh psikososial dan lingkungannya, yang paling mendominasi bagi para perempuan lansia adalah permasalah ekonomi pada keluarga yang mengharuskan mereka ikut serta dalam pemenuhan kebutuhan keluarga.

\section{PENDAHULUAN}

Menurut WHO tahun 2013 diperkirakan tahun 2020 akan mengalami peningkatan yang sangat cepat, di mana 6,9 milyar penduduk adalah lansia. Lansia salah satu populasi berisiko yang berarti memiliki kemungkinan buruk karena faktor resiko biologis, risiko sosial, resiko lingkungan dan resiko perilaku. Berdasarkan Badan Pusat Statistik (BPS) tahun 2017 hampir lima dekade terakhir menunjukkan peningkatan dua kali lipat mulai tahun 1971 sampai 2017 yaitu 8,97 \% atau sekitar 23,5 juta dimana perempuan lansia lebih banyak $1 \%$ dibanding lansia laki laki.

Menurut data statistic BPS tahun 2009, terdapat 12 provinsi yang penduduknya berstruktur tua (jumlah lansia lebih dari 7\% total penduduk salah satunya Sulawesi Selatan. Khususnya di kota Makassar berdasarkan sensus penduduk dari BPS tahun 2010 jumlah lanjut usia yang lebih 60 tahun mencapai $8,34 \%$.

Masa lansia biasanya dimulai dari pensiun yaitu 60 sampai 70 tahun. Proses lansia ini adalah proses yang alamiah dan tidak dapat dihindari dan berkesinambungan (Depkes RI. 2001) Permasalahan umum yang dihadapi perempuan lansia adalah makin besar jumlah perempuan lansia di bawah garis kemiskinan, makin melemahnya kekerabatan dalam keluarga terkadang mereka kurang mendapatkan perhatian, dihargai dan dihormati, kurangnya pelayanan lansia dari tenaga professional, dan belum melembaga dan membudaya pembinaan kesejahteraan lansia khususnya perempuan lansia.

Sedangkan secara khusus, yang menjadi permasalahan pada perempuan lansia adalah adanya proses penuaan yang mengakibatkan pada masalah fisik, mental dan sosialnya, berkurangnya integrasi sosial, rendahnya produktifitas kerja perempuan lansia, keterlantaran perempuan lansia

Sebagian besar perempuan lansia memiliki kesulitan pada upaya mereka untuk mengatasi proses penuaan. Akan tetapi, banyak penelitian sebelumnya mengatakan bahwa kualitas hidup lanjut usia yang 
tinggal di panti lebih rendah daripada di rumah.

Ini menjadi tanda rendahnya kualitas hidup dilanjut usia dikarenakan mereka tidak menikmati masa tuanya. Kualitas hidup yang dimaksud adalah sejauh mana seseorang merasakan dan menikmati terjadinya segala peristiwa yang penting dalam hidupnya sehingga kehidupannya sejahtera dan jika sebaliknya jika seseorang mencapai kualitas hidup yang rendah, maka kehidupan mengarah ketidaksejahteraan (Brown. 2004)

Kualitas hidup lansia dipengaruhi berbagai faktor seperti kesehatan fisik, kesehatan psikologis, hubungan sosial dan lingkungan. Maka diperlukan kemampuan atau kapasitas dalam mengahadapi dan mengatasi berbagai permasalahan hidup secara positif sehingga perempuan lansia memandang permasalahan tersebut sebagai hal yang wajar.

Berdasarkan uraian di atas maka rumusan masalah dari penelitian ini adalah mengidentifikasi faktor dominan yang mempengaruhi kualitas hidup perempuan lansia dan bagaimana ketahanan perempuan lansia.

\section{METODE PENELITIAN}

Pembagian konsep usia terdiri atas usia pertengahan yaitu 45 sampai 59 tahun, lanjut usia antara 60 sampai 74 dan lanjut usia tua antara 75 sampai 90 dan usia sangat tua di atas 90 tahun.

Kriteria pada penelitian ini berusia 60 - 74 tahun atau 75 sampai 90 tahun, mampu berjalan, dapat membaca dan menulis, tidak mengalami gangguan komunikasi dan perempuan lansia yang tinggal sendirian dilingkungan masyarakat akan tetapi tidak sama sekali menunjukkan kesepiannya dan bersedia menjadi responden Adapun dalam melakukan penelitian peneliti mewawancarai sebelas perempuan lansia di kota Makassar dikarenakan jawaban yang didapatkan memenuhi isi pertanyaan yang diajukan dalam pedoman wawancara

Penelitian ini menerapkan metode deskriptif kualitatif dengan pendekatan penelitian dalam pandangan fenomelogis yang berusaha memahami arti dari peristiwa dan kaitannya terhadap orang dalam situasi tertentu. Sumber data dalam penelitian ini dipilih secara purposive sesuai dengan kriteria dalam penelitian ini. Teknik pengumpulan data yang peneliti lakukan adalah dengan observasi, wawancara dan dokumentasi serta observasi berdasarkan indicator yang disusun WHO antara lain kesehatan fisik, psikologis, kemandirian, hubungan sosial dan lingkungan

Untuk keabsahan data maka dilakukan trianggulasi yaitu tranggulasi dengan sumber (mengecek kembali suatu informasi yang diperoleh), trianggulasi dengan metode dan trianggulasi dengan teori. 
Penelitian ini menggunakan metode penelitian kepustakaan (library research) yaitu penelitian yang kajiannya dilakukan dengan menelusuri dan menelaah literatur yang relevan dengan topik yang menjadi objek penelitian. Sumber data dalam penelitian ini diperoleh dari berbagai karya tulis seperti buku, makalah, internet, artikel, skripsi, tesis, disertasi dan sumber-sumber lainnya yang ada hubungannya dengan masalah yang diteliti. Dalam penelitian kepustakaan ini, pengumpulan data baik primer maupun sekunder dilakukan peneliti dengan pengumpulan data non-lapangan, oleh karena itu peneliti dapat memanfaatkan semua informasi dan pemikiran yang relevan dengan objek penelitian yang dilakukan (Prastowo, 2016: 191).

Teknik analisis data dalam penelitian ini menggunakan metoda analisis isi (Content Analysis), yaitu teknik analisis dengan cara memilih, membandingkan, mengabungkan dan memilah berbagai pengertian sehingga ditemukan data yang relevan dan mendasar untuk dijadikan langkah dalam pengambilan kesimpulan (Moleong, 2006: 289).

\section{HASIL PENELITIAN DAN PEMBAHASAN}

Kesiapan lansia untuk menyesuaikan diri terpengaruh oleh proses tumbuh kembang sebelumnya.

Di mana perkembangan lansia menurut Maryam dkk (2008) yaitu kesiapan diri untuk kondisi yang menurun, kesiapan untuk kehidupan yang baru, menyesuaikan terhadap kehidupan masyarakat dan kesiapan menerima kematian pasangan.

Pada umumnya perempuan lansia dapat beradaptasi tinggal dirumah sendiri daripada tinggal keluarga sendiri (anak).

Berdasarkan hasil penelitian ditemukan beberapa tipe perempuan lansia yaitu : tipe pasrah yang menerima nasib, tipe mandiri yaitu bersifat selektif da nada aktifitas yang dilakukan, dan tipe perempuan lansia yang arif yaitu perempuan lansia ini dapat menyesuaikan diri dengan perubahan. Pendidikan responden sebagian besar adalah lulusan sarjana dan sebagian besar berstatus sebagai janda.

Berdasarkan hasil penelitian, perubahan yang terjadi pada perempuan lansia meliputi perubahan fisik, perubahan psikososial dan perubahan lingkungan. Dari hasil penelitian sebagian besar responden memiliki kualitas hidup yang sedang.

\subsection{Pengaruh Fisik Perempuan Lansia}

Perubahan fisik yang terjadi meliputi perubahan sel, persyarafan yang mengakibatkan menurunnya serta melambatnya respon, sehingga menyebabkan berkurangnya respon motoric dan reflex dan juga usia lansia sangat mudah rapuh dan bungkuk dan biasanya memori banyak mengalami penurunan

Sedangkan intelegensi secara umum tidak banyak mengalami perubahan begitupun personality atau 
pengaturan serta pencapaian seperti sains, seni dan musik tidak banyak berubah.

Perubahan fisik yang terjadi pada perempuan lansia dapat diperbaiki dan dihilangkan melalui nasehat (pembinaan) atau tindakan medik (pelayanan kesehatan).

Berdasarkan hasil penelitian kondisi fisik akan mengalami penurunan dalam kehidupannya. Namun ketidaksiapan akan memperllihatkan rendahnya pencapaian kualitas hidupnya. Kondisi fisik inilah yang akan membuat perempuan lansia akan merasa putus asa.

. Dengan kondisi fisik yang baik, perempuan lansia masih dapat melakukan semua aktifitas yang diinginkannya, sesuai dengan porsi sebagai usia lansia, kegiatan yang sering dilakukan sebelumnya akan berkurang dikarenakan terlalu berat untuk sesusianya.

\subsection{Pengaruh Psikososial Perempuan Lansia}

Kestabilan kesejahteraan secara psikologis yang ikut menentukan kesejahteraan, dapat terlihat dari kesehatan psikologi seperti spritualitas, berfikir, memori, konsentrasi dan gambaran diri.

Bagi seseorang yang memasuki usi lanjut, berbagai kecenderungan memperlihatkan kemampuan yang salah satunya adalah perubahan psikologis yang dimaksud adalah sikap frustasi, takut kehilangan, kesepian, depresi, kecemasan dan perubahan keinginan. Masalah psikologi pada perempuan lansia biasanya terjadi karena transisi peran pada lingkungan sosialnya, kehilangan dan perubahan fisiologis dan kematian.

Berdasarkan dari hasil penelitian perempuan lansia yang tidak mendapatkan perhatian anak atau kematian suami ini yang menjadikan pemicu rasa kesepian. Pada perempuan lansia perubahan social dipengaruhi pada pemahaman mereka atas dirinya sendiri.

Biasanya perempuan lansia yang mengalami perubahan psikologis akan secara perlahan menarik diri dari hubungan dengan masyarakat sekitar sehingga mereka menarik diri dan hal tersebut biasa nya yang mempengaruhi interaksi.

Berdasarkan hasil penelitian dari sebelas perempuan lansia, bahwa faktor psikologis merupakan faktor yang penting untuk melakukan kontrol terhadap semua kejadian yang dialami. Dikarenakan perubahan psikologis berasal dari kesadaran yang merosot. Hal ini yang membuat perempuan lansia merasa tidak aman dan merasakan penyakit akan selalu datang menghampiri dirinya.

Secara umum perempuan lansia cenderung memiliki gangguan mental yang lebih rendah dan lebih bahagia. Indikator kesehatan mental ini cenderung meningkat di usia tua.

Dalam penelitian ini para perempuan lansia masih tergantung pada fisik dan psikososialnya diantara 
lain perempuan lansia kehilangan atau pendapatan yang berkurang akibat pensiun dan tidak mampu bekerja seperti semasa mereka masih memiliki kemampuan secara fisik. Perubahan atau ganguan pada syaraf panca indra. Perasaan kesepian dan keasingan di lingkungan keluarga maupun sosialnya.

Bagi perempuan lanjut usia, kehilangan perhatian dan dukungan dari lingkungan social yang biasanya terkait dengna hilangan otoritas atau kedudukan, dapat menimbulkan konflik atau keguncangan. Aktivitas seperti spiritual akan memberikan nilai tertinggi pada seorang lansia terutama lansia perempuan. Mereka menjadi mampu bertahan dan bersyukur serta melanjutkan kehidupannya di masa tua nya. Kualitas hidup yang berkaitan dengan hubungan sosial dipengaruhi banyak hal oleh perempuan lansia salah satunya dukungan sosial, coping terhadap stress dan persepsi.

Salah satu perubahan sosial adalah adanya perubahan peran, keluarga, keberfungsian keluarga (ekonomi, rekreasi, keamanan, politik, pendidikan dan agama) dan teman, Dengan aktif di dalam aktivitas sosial, ini sebagai ajang untuk saling bertukar pikiran dan saling memberikan perhatian. salah satu dukungan sosial terutama teman sebaya lansia sangat berpengaruh. Perempuan yang cenderung sendiri tanpa melakukan hubungan sosial mereka dan berdiam diri di rumah, maka perempuan lansia tersebut merasakan kesepian.

Berdasarkan hasil penelitian perempuan lansia yang memiliki hubungan sosial yang buruk atau cukup sebagian besar memiliki kualitas yang rendah dan sebaliknya lansia yang memiliki kualitas hidup yang tinggi memiliki hubungan sosial yang baik. Dari hasil penelitian juga menunjukkan lansia yang tinggal dirumah dan mendapatkan dukungan keluarga akan mengalami perubahan yang positif dibandingkan dengan perempuan lansia yang tinggal di panti, karena perempuan lansia merasa tidak mendapatkan dukungan dari keluarga dan masyarakat.

Dalam penelitina ini proses adaptasi perempuan lansia yang mereka lalui tidaklah mudah mengingat dengan segala keterbatasan yang dimiliki lansia, akan tetapi hal itu tidak membuat mereka menyerah.

Persepsi seseorang tentang posisinya dalam hidup kaitannya dengan sistem nilai yang berhubungan dengan tujuan, harapan serta budaya. Pentingnya pemahaman atau pengenalan. Dengan tercapainya lingkungan yang sejahtera akan mendukung perempuan lansia dalam memperoleh kualitas hidupnya. Memiliki aktifitas dan masih mampu menghasilkan sesuatu merupakan salah satu cara menjaga kualitas hidup

\subsection{Ketahanan Perempuan Lansia}

Berdasarkan hasil penelitian perempuan lansia dapat mengatasi permasalahan dengan faktor internal dan eksternal, dimana faktor internal antara lain kemampuan dalam pengaturan emosi, optimism, kemampuan menganalisis masalah. Sedangkan faktor eksternal biasanya berasal dari 
lingkungan sekitar antara lain; hubungan denga lingkungan sekitar, dukungan sosial dan faktor pendapatan dan juga perempuan lansia dapat mengisi kekosongan membuat perempuan lansia tetap aktif untuk bekerja.

Dari permasalahan yang dihadapi perempuan lansia antara lain karena pengaruh fisik, pengaruh psikososial dan lingkungannya, yang paling mendominasi bagi para perempuan lansia adalah permasalah ekonomi pada keluarga yang mengharuskan mereka ikut serta dalam pemenuhan kebutuhan keluarga.

Bukan hal yang telah disebutkan di atas, ada beberapa hal yang dapat mempengaruhi perempuan lansia untuk menjalankan kehidupannya, yaitu aspek produktifitas kerja bahwa perempuan lansia bebas dari ketergantungan, adanya nilai nilai spritualitas, pandangan hidup.

\section{KESIMPULAN}

Jika usia perempuan lansia mampu mengaktualisasikan potensinya secara optimal, maka perempuan lansia dapat mempertahankan pola hidup dan cara pandang untuk memaknai kehidupan, maka mereka akan dapat melakukan atau berbuat banyak bagi kepentingan semua orang.

Saran, sebaiknya perempuan lansia mendapatkan pelayanan kesehatan baik secara psikis dan sosial serta lebih memperdalam pendekatan spiritual mereka sendiri karena hal ini merupakan kepuasan batin

\section{DAFTAR PUSTAKA}

Arikunto, Suharsimi. 2006. Metodologi Penelitian Suatu Pendekatan Praktik. Jakarta : Rineka Cipta Brown, Jackie. 2004. Models of quality of live. European Forum.

Gufron. Mukti Ali. 2012. Memanusiakan Lanjut Usia. Yogyakarta : Perpustakaan nasional. Irwan. 2014. Mengenal Usia Lanjut dan Perawatannya. Jakarta : Salemba Medika Lexy, J. Moleong. 2007. Metodology penelitian Kualitatif. Bandung ; PT. Remaja Rosdakarya. Maryam, S., dkk. 2008. Mengenal USia Lanjut dan Perawatannya. Medika : Jakarta. Mendes, Stefanus dkk. Journal Keperawatan Indonesia. NTT.

Moleong, Lexy J. 2007. Metodologi Penelitian Kualitatif. Bandung : Remaja Rosdakarya. Notoadmojo, S. 2008. Kesehatan Masyrakat Ilmu dan Seni. Jakarta : Rineka Cipta. Sarminto. 2012. Memanusiakan Lanjut Usia. Yogyakarta : Perpustakaan nasional. Suharto, Edi, dkk. 2011. Kemiskinan dan perlindungan sosial di Indonesia. Bandung : Alfabeta 